\title{
Do Environmental Compliances Reduce Agricultural Profitability? An Inference from Indonesia
}

\author{
Ahmad Abbas ${ }^{1, *}$, Neks Triani $^{2}$, Sasmita Nabila Syahrir ${ }^{2}$, and Andi Ayu Frihatni ${ }^{3}$ \\ ${ }^{1}$ STAIN Majene, West Sulawesi, Indonesia \\ ${ }^{2}$ Universitas Sembilanbelas November Kolaka, Southeast Sulawesi, Indonesia \\ ${ }^{3}$ IAIN Parepare, South Sulawesi, Indonesia
}

\begin{abstract}
This research seeks to find the effect of environmental compliances on profitability in the agricultural business sector. This research is quantitative by testing the nexus between environmental compliances (environmental cost and reputational incentive) and agricultural profitability. The sample of this study identified agricultural public firms in Indonesia including five sub-sectors consisting of farming, fisheries, livestock, plantation, and forestry. Financial statements and annual reports in terms of the environment were utilized in this research. Final samples were 12 public agricultural companies. The research model was analysed using the regression with common, fixed and random effect models and were checked the robustness using Generalized Method of Moment (GMM). The result of this research found no effects on the nexus between environmental cost and profitability. It indicates that the environmental cost spent by agricultural firms doesn't reduce the profitability. The emerging effect can be found on reputational incentive leading the increase into the extent of agricultural profitability both return on assets and return on equity.
\end{abstract}

\section{Introduction}

Agricultural industry refers to business sector with the activity of utilizing biological resources to produce food, industrial raw materials, or energy sources, and to have the responsibility to manage the impact of the environmental practices enabling emerge as a result of the production process[1]. The agricultural sector has the strategic role due to leading the national growth. As noted by Central Bureau of Statistics of Indonesia [2], the agricultural sector in 2020 grew with 2.59 percent (year on year). Future agricultural outlook will have big potential to be a drive sector in the market industry to improve the economy. Moreover, agriculture sector could provide an increasing effect on the economy if they perform their operational business well [3]. Public companies in agricultural sector have strong power in determining the economy. They should be highlighted because of having the production potential damaging the society and decreasing the quality of

\footnotetext{
* Corresponding author: ahmad.abbas@stainmajene.ac.id
} 
environment. The demand on the environmental maintenance deriving from stakeholders particularly the government leads companies into the implementation of environmental performances. If companies could provide positive impacts on the environmental practices, their existence would obtain good a feed-back from stakeholders.

The agricultural industry can't be separated with environmental performances. The performance of the environment makes a company manage the waste disposal and use raw materials well without damaging the environment[4]. The effort of reducing chemicals should be carried out to maintain the environmental condition of agricultures. If production costs increase, the use of chemical materials will be excessive resulting in losses to land and environmental sustainability [5]. For controlling the performance of companies in the excessive production process, the environmental benchmark should be made. The environmental performance rating assessment program known as PROPER is the initiative developed by the Ministry of Environment with the purpose of promoting the compliance as well as providing incentives to firms following the required regulation. This issue in the context the environmental compliance becomes significant to discuss. The Ministry of Environment and Forestry just has released the result of PROPER. The report disclosed that ninety-five companies in agricultural sectors composed of fisheries and plantation (rubber and palm) in 2020 obtained Red rating indicating that such companies have poor environmental compliances [6]. They couldn't comply with the regulation because PROPER brings fewer benefits on the performance [4]. On behalf of financial benefits, companies may be encountered by a paradigm that cost and incentive to consider the environment activities both internal and external sides are not a key to affect the profitability. Even more there are no empirical consensuses that environmental compliances don't take great spaces to lead into the increase of company profitability and prior studies still provides unclear findings to withdraw inferences in terms of the profitability and environment performance [7-12]. That's why, this research comes up to fill the gap in the literature by documenting valuable insight into the nexus between environmental compliances and profitability and to respond the assumption that companies benefit under environmental compliances empirically affecting the profitability. In a different manner with a large number of previous studies conducting the analysis in the manufacturing areas, this research focuses on agricultural areas. Since environmental performances have been mandatory through PROPER, companies should do compliance with the regulation required by the Indonesian government through the Ministry of Environment. This research is also designed to use of profitability of ROE as the independent variable for alternative profitability proxy aiming to avoid any potential measurement biases so that the result of this research is robust to alternative econometric estimation methods. This research can additionally contribute to the future agricultural outlook and body of knowledge in the context of agricultural economics. The purpose of this research therefore is to test the effect of environmental compliances on the profitability. Cost and impact sides are identified in this research as signals to the compliance. The cost spent by companies for the environment becomes a material sacrifice leading into the reputational incentives referred to this research as the impact.

\subsection{Legitimacy Theory and Hypothesis Development}

Legitimacy is a status and refers to a license approved by the community [13] and is related to any resources that an organisation should acquire from its environment [14]. Under the theory of legitimacy, the tenet discloses that the organization continually attempts to ascertain that it performs with the bounds and standards of the community [15] and is an underpinning to elaborate the fulfilment of the value of life. The consideration from outside 
parties should be reached to obtain the value [4]. Legitimacy theory aids to assert corporate environmental performances [16].

Companies are encouraged to obey more regulations when they tend to obtain the number of environmental laws and pressures from stakeholders. Companies with environmental involvements could be competitive advantages among competitors [17]. Awareness of environments can increase the business reputation in the eyes of the customer $[18,19]$ and the extent of productivity in front of shareholders [20].

This research emphasizes on cost and impact. Based on cost, environmental compliances may need to spend the cost. The profitability decreases when companies couldn't maximize the revenue. The spent cost in terms of environment would less reduce the revenue but wouldn't lead the losses. The reason is that the magnitude of the expenditure of environment costs can't be compared with the expenditure of other dimensions, such social costs, and administration expenses. It means that the dimension of the environment cost has less economic consequence. The environmental performance in the cost perspective is only regarded as the regulation in which it requires the post of cost allocations in the report system. This research hypothesizes no effect on the nexus between agricultural cost and profitability. The function of cost tends to be a reduction in income in the accounting system, but the cost in terms of environments will make the impact on company reputations. If those increase, investors will be the economic partner through stock investment. To sum up, companies may assume that the reduction is addressed to find the impact. In the perspective of the impact, companies otherwise expect the feed-back from what they have performed, although environmental compliances may be very costly. Environmental cost is one of the determinants of the success of environmental management accounting. It can increase the quality of financial decision by considering the quality of environmental decision [21]. The environmental cost in accounting system serves as an instrument for controlling the environment practices so that companies can obtain information concerning cost and revenues [22]. They may utilize information in the matter of the cost as the effort of the fulfilment of value deriving from the regulation and stakeholders. Furthermore, Indonesian government has made environmental compliances with the regulation in terms of environmental activities. Those are bringing the impact on the reputation. For impact sides, the proxy variable used is reputational incentives expected by firms tend to lead into the increase of profitability. As far as legitimacy theory is concerned, agricultural costs assumed by firms have no effect on the profitability, however it is reasonable to state that companies couldn't maximize the environmental practice unless the expected profitability warrants the costs leading into better performance [23]. The reputation value affects the company's existence through the corporate social responsibility for environments [24]. The investor can be more interested to invest in the company considering the environment-oriented responsibility. Therefore, the cost spent by agriculture companies has no effect at all in the level of profitability, but positive effect emerges after complying with the environmental regulation and obtaining color coded rating as a part of reputational incentive. This research develops the following hypotheses:

H1. Agricultural cost has no effect on profitability.

H2. Reputational incentive has a positive effect on profitability.

\section{Method}

The type of this research is quantitative testing the nexus between variables. One of the major areas of agriculture is agricultural economics. Related to the population, this research highlighted all public agricultural business sectors listed during the latest five periods in Indonesia Stock Exchange. Public companies in the agricultural sector have strong power in determining the economy because they are large firms with wide-range stakeholders. They 
should be highlighted because of having the production potential damaging the society and decreasing the quality of environment. They were made up of five sub-sectors consisting of farming, fisheries, livestock, plantation, and forestry. The sample used public firms listed on Indonesia Stock Exchange. This research eliminated 15 firms of 31 firms due to financial data unavailability and incomplete data. Thus, final samples were 16 firms of 31 firms.

Financial statements and reports over the period of 2015-2019 in terms of environment activities were analysed. The data used in the analysis were derived from the database of Indonesia Stock Exchange. Total observations were 80 units. This research proposes the following model for panel data:

$$
R O A_{i t}=f\left(C O S T_{i t}, P R O P E R_{i t}, X_{i t}\right)+\varepsilon_{i t}
$$

Where, firm $i$ in period $t$, ROA is profitability used to denote a function of COST (environmental cost), PROPER (reputational incentive), and X (set of control variables believed to be related to ROA. Based on the accounting system, environmental activities are disclosed in form of recording the account of environmental cost and the report of environmental corporate social responsibility. In this research, environmental cost is internal and external costs related to the environment spent by companies and measured as the environmental cost divided by the net income before tax. Internal cost denotes the direct monetised expenditures including planning, construction, management, maintenance, and disposal for a company operating an activity, and external cost denotes externalities in terms of the economic concept of environmental effects such as polluter pay $[22,25]$. The report of environmental corporate social responsibility is an evidence of the disclosure of environmental involvements undertaken by companies.

In addition to another main variable, this research uses reputational incentive measured as the environmental performance ratings. The program of the ratings in Indonesia known as PROPER is an incentive regulation system to improve environmental performance [26]. It provides the status of compliance so as to build more business images [4]. The status is a color coded rating (Gold, Green, Blue, Red, and Black) and is used to reward companies undertaking good environmental performance (Gold, Green, and Blue) and to penalize the noncompliant polluter (Red and Black). Gold rating indicates excellent environmental performance; Green rating denotes good environmental performance, and Blue rating shows adequate environmental performance implemented by companies. Red and Black is poor and very poor respectively. This research uses ordinal scales (Gold=5, Green=4, Blue $=3$, $\operatorname{Red}=2$, and Black $=1$ ).

For testing the nexus between variables, the appropriate proxy variables should be identified. This research employs ROA measured as the net income divided by average total assets. It is an obvious proxy for evaluating the profitability. ROA denotes the amount of profit earned from the assets. This research model incorporates a set of control to consider potential agricultural business-characteristics. Firm size and age are included in the model. Both are symbolized as SIZE and AGE respectively. SIZE is measured by the natural logarithm total assets and AGE is obtained using the number of years since samples are listed as the public firm.

The analysis of the panel data requires the selection of the test of regression model, whether to use common effect, fixed effect, or random effect. Each model is written as follows $[27,28]$.

$$
\begin{aligned}
& \mathrm{ROA}_{i \mathrm{it}}=\beta 0+\beta 1 \mathrm{COST}_{\mathrm{it}}+\beta 2 \mathrm{PROPER}_{\mathrm{it}}+\beta 3 \mathrm{AGE}_{\mathrm{it}}+\beta 4 \mathrm{SIZE}_{\mathrm{it}}+\varepsilon_{\mathrm{it}} \ldots \ldots \text {. Common Effect } \\
& \mathrm{ROA}_{\mathrm{it}}=\beta 0+\delta 1 \mathrm{D} 1+\delta 2 \mathrm{D} 2+\delta 3 \mathrm{D} 3+\delta 4 \mathrm{D} 4+\beta 1 \mathrm{COST}_{\mathrm{it}}+\beta 2 \mathrm{PROPER}_{\mathrm{it}}
\end{aligned}
$$

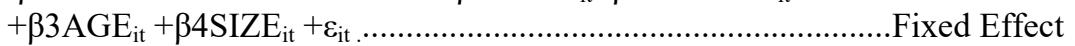

$$
\begin{aligned}
& \mathrm{ROA}_{i \mathrm{it}}=\beta 0+\beta 0 \operatorname{COST}_{\mathrm{it}}+\beta 2 \mathrm{PROPER}_{\mathrm{it}}+\beta 3 \mathrm{AGE}_{\mathrm{it}}+\beta 4 \mathrm{SIZE}_{\mathrm{it}}+\mu_{\mathrm{it}}+\varepsilon_{\mathrm{i}} \ldots . \text { Random Effect }
\end{aligned}
$$


To obtain a consistent result, profitability should also be determined in stock evaluation. This research requires a robustness check by adding ROE as profitability proxy. ROE is most widely used overall proxies of corporate financial performances [29] and becomes so interesting for shareholders [30]. ROA and ROE are two historical accounting returns considered for investors to choose the stock [31]. Both performances are traditional measurements of performance. In addition to the robustness check, the model of this research employs the appropriate estimation method of Generalized Method of Moments (GMM) for comparison purposes and to ensure that the results of this research are robust and insensitive to any estimation method.

\section{Results and Discussion}

The result of this research presents descriptive statistics, estimation method tests, and robustness checks. Further subsection presents the discussion concerning the hypothesized nexus between environmental compliances and profitability.

\subsection{Descriptive Statistics}

Having obtained final samples, summary statistics of sample companies is presented in Table 1 and descriptive statistics regarding the variables of this research is in Table 2 . The sample companies are presented in profitability, environmental cost, reputational incentive, and firm size. During the latest five periods, profitability proxied by ROA has obtained negative and positive values. The value of ROA interprets the higher the ROA generated by companies the greater the financial performance. A good value of ROA is above zero percent or in a positive value. Sawit Sumbermas Sarana has been the sample firm with the highest positive values (11.62). The value indicates that Sawit Sumbermas Sarana has been more effective to use the asset in gaining greater income. On the other hand, a company with negative value indicates bad profitability and with positive value shows good profitability. The samples with the highest negative value have been suffered by Gozco Plantations (-18.05) and by Bakrie Sumatra Plantations (-18.49). Companies with negative profitability have suffered high losses during undertaking the business.

Table 1. Profitability, Cost, Incentive, and Firm Size

\begin{tabular}{|l|r|r|c|c|}
\hline \multicolumn{1}{|c|}{ Agriculture Name } & $\begin{array}{c}\text { Average } \\
\text { ROA }\end{array}$ & $\begin{array}{c}\text { Average Cost } \\
\text { (Million) }\end{array}$ & Incentive & $\begin{array}{c}\text { Average } \\
\text { Firm Size }\end{array}$ \\
\hline Astra Agro Lestari & 5.22 & 93,412 & 3.60 & 30.84741 \\
\hline Eagle High Plantations & -2.61 & 34,083 & 3.00 & 30.42788 \\
\hline Dharma Satya Nusantara & 3.96 & 15,732 & 4.00 & 29.63638 \\
\hline Gozco Plantations & -18.05 & 2,765 & 3.00 & 28.84585 \\
\hline Jaya Agra Wattie & -5.90 & 1,146 & 3.00 & 28.85032 \\
\hline PP London Sumatra Indonesia & 5.32 & 29,076 & 3.00 & 29.90444 \\
\hline Multi Agro Gemilang & -9.69 & 2,651 & 3.00 & 27.78412 \\
\hline Provident Agro & -0.37 & 2,324 & 3.00 & 28.77858 \\
\hline Sampoerna Agro & 2.62 & 11,955 & 3.00 & 29.70075 \\
\hline Salim Ivomas Pratama & 0.73 & 95,863 & 3.00 & 31.14359 \\
\hline Smart & 3.56 & 74,874 & 3.00 & 30.92354 \\
\hline Sawit Sumbermas Sarana & 11.62 & 31,108 & 3.00 & 29.86123 \\
\hline Tunas Baru Lampung & 4.46 & 20,016 & 3.00 & 30.26932 \\
\hline Bakrie Sumatra Plantations & -18.49 & 28,998 & 3.00 & 30.20851 \\
\hline BISI International & 0.13 & 4,498 & 3.00 & 28.57774 \\
\hline Dharma Samudera Fishing & 0.02 & 361 & 3.00 & 26.60539 \\
\hline
\end{tabular}


The cost related to activities affecting the environment is presented in million Rupiah. The highest average cost of 95,863 was spent by Salim Ivomas Pratama over the period of 2015-2019. Otherwise Darma Samudera Fishing was the sample company spending the average cost with the lowest value of 361 . For incentives, PROPER is employed to assess the environmental performance. As marked in colour coded rating assigning Gold to 5, Green to 4, Blue to 3, Red to 2, and Black to 1, Dharma Satya Nusantara has been the only sample company to achieve Green for observation periods, and Astra Agro Lestari has obtained Green for three times, and the rest always obtained Blue. Blue incentives show that the company has complied with the regulation and Green incentives indicate that the company has been obedient and has worked more than what is required by regulation. For firm size calculated as the natural logarithm of total assets, the average value over periods showed varying sizes. Salin Ivomas Pratama was the sample company obtaining the greatest firm size.

Variable descriptive statistics is presented in Table 2. For dependent variable, the mean value of Profitability variable labelled using ROA was $0.03 \%$. It shows that the average value of profitability gained by sample companies is above zero indicating good financial performances. Environmental compliances are proxied using COST and PROPER. For COST, the mean ratio obtained $2.00 \%$. It shows positive value with small ratio indicating that the cost for environmental compliances is more spent by the average companies gaining net income. Related to PROPER variable, the average value obtained 3.10 showing that the average companies have reputational incentives with Blue rating. As measured by the 5-color rating system (Gold, Green, Blue, Red, and Black), companies have complied with the regulation. They have been a safe zone in environmental compliance. Beside independent variables, control variables are also employed in this research (AGE and SIZE). Companies have average age value approximately 11.06 years and their sizes are great with value of 29.50 in the natural logarithm.

Table 2. Variable Descriptive Statistics

\begin{tabular}{|l|c|}
\hline \multicolumn{1}{|c|}{ Variable Name and Measurement } & Mean \\
\hline $\begin{array}{l}\text { Profitability (ROA) } \\
\text { Ratio between net income and total assets }\end{array}$ & 0.03 \\
\hline $\begin{array}{l}\text { Environmental Cost (COST) } \\
\text { Ratio between the environmental cost and the net income before tax }\end{array}$ & 2.00 \\
\hline $\begin{array}{l}\text { Reputational Incentives (PROPER) } \\
\text { Program of the environmental performance ratings based on the compliance }\end{array}$ & 3.10 \\
\hline $\begin{array}{l}\text { Agriculture Age (AGE). } \\
\text { The age of business }\end{array}$ & 11.06 \\
\hline $\begin{array}{l}\text { Agriculture Size (SIZE). } \\
\text { The natural logarithm of total assets. }\end{array}$ & 29.50 \\
\hline
\end{tabular}

\subsection{Result of Estimation Method Test}

Before testing the hypotheses, regression model should be tested. Table 3 presents the results of panel data estimation methods, namely Common Effect Ordinary Least Square (OLS), Fixed Effect (FEM), and Random Effect (REM). For the variables of COST and AGE, the regression coefficients in all models are insignificant at all the level of $0.01,0.05$ and 0.10 . The variable of SIZE otherwise shows significance at the 5 percent in all regression models. For PROPER variable, fixed effect obtains significant value at 1 percent level, and the random effect shows significant regression coefficient at the 10 percent. The selection of panel data regression models further is determined based on Chow test, Hausman test, and or Lagrange Multiplier test. 
Table 3. Regression Model Test

\begin{tabular}{|l|l|l|l|}
\hline Regressors & Common Effect & Fixed Effect & Random Effect \\
\hline COST & -0.96 & -2.82 & -4.06 \\
& -0.09 & -0.35 & -0.47 \\
\hline PROPER & 3.83 & -39.89 & -12.16 \\
& 0.68 & $-4.01^{* * *}$ & $-1.61^{*}$ \\
\hline AGE & -0.02 & 0.82 & -0.07 \\
& -0.13 & 0.93 & -0.22 \\
\hline SIZE & 3.12 & 18.61 & 4.73 \\
& $2.11^{* *}$ & $2.56^{* *}$ & $2.01^{* *}$ \\
\hline Constant & -103.76 & -434.59 & -100.89 \\
& $-2.40^{* *}$ & $-2.00^{* *}$ & -1.46 \\
\hline R-Squared & 0.07 & 0.27 & 0.24 \\
\hline F Test & 1.49 & $5.67^{* * *}$ & \\
\hline Wald chi2(2) & - & - & 6.08 \\
\hline Prob $>$ Chi2 & - & - & 0.19 \\
\hline Chow Test & - & $5.17^{* * *}$ & - \\
\hline Hausman test & - & $22.49^{* * *}$ & - \\
\hline Number of Observations & 80 & 80 \\
\hline$* * * 0.01, * * 0.05, * 0.10$ & \multicolumn{3}{l}{} \\
\hline Dependent Variable $=$ ROA & \\
\hline
\end{tabular}

As shown in Table 3, Chow specification test obtained 5.17 at the 0.01 level $(<0.05$ level). It means that the model favours the fixed effects estimator (FEM). The test further allowed for comparison with random effect (REM) through Hausman specification test. The result obtained 22.49 at the 0.01 level under the established significance level of 0.05 . Thus, the regression model favours fixed affects estimator (FEM). Before deciding the inference of the fixed effect model, diagnostics of all regressors should be tested as shown in Table 4 as follows.

Table 4. Fixed Effect Regression Diagnostics

\begin{tabular}{|l|l|}
\hline Regressors & VIF \\
\hline COST & 1.03 \\
\hline PROPER & 1.05 \\
\hline AGE & 1.11 \\
\hline SIZE & 1.15 \\
\hline Mean & 1.08 \\
\hline White test & $\begin{array}{l}\text { Chi-square }=4.15 \\
\text { Prob }>\text { Chi-square }=0.98\end{array}$ \\
\hline Breusch Pagan/Cook-Weisberg test & $\begin{array}{l}\text { Chi-square }=3.33 \\
\text { Prob }>\text { Chi-square }=0.07\end{array}$ \\
\hline
\end{tabular}

To assess whether one or more predictor variables explain the dependent variable. The regression model with fixed effect should have no multicollinearity and heteroscedasticity. In Table 4, All VIF values are below the threshold of 10 with the mean of 1.08. In the regression, homoscedasticity is present with probability chi-square more than 0.05 as shown in White and Breusch Pagan/Cook-Weisberg tests. Therefore, the result of regression model test with fixed effect can be used to discuss the nexus between variables.

\subsection{Robustness Check}

This research employed robustness checks to allow for comparison with fixed effect model. The robustness checks aim to confirm results consistency and validity. Table 5 presents results from regression analysis using ROE as the dependent variable and GMM test. 
This research employed profitability proxy variable of ROE for comparison with ROA. As shown in Table 5, Chow test is used to choose appropriate regression model, common or fixed effects. The result of the test obtained 6.19 under 0.05 level so that fixed effect model was appropriate regression estimation. Further test compares fixed effect and random effect models identified using Hausman test. The result of Hausman obtained 5.43 greater than 5 percent. Because of Hausman test to provide the significance more than 0.05, Lagrange Multiplier test was required to choose between random effect (REM) and common effect (POLS). The result of the test obtained 36.23 significant at the 0.01 level. It means that the regression model favours random effects estimator (REM).

Table 5. Regression Model Test for the Dependent Variable of ROE

\begin{tabular}{|c|c|c|c|}
\hline Regressors & $\begin{array}{l}\text { Common } \\
\text { Effect }\end{array}$ & Fixed Effect & Random Effect \\
\hline COST & $\begin{array}{l}0.28 \\
0.02\end{array}$ & $\begin{array}{l}-14.95 \\
-1.14 \\
\end{array}$ & $\begin{array}{l}-13.90 \\
-1.08 \\
\end{array}$ \\
\hline PROPER & $\begin{array}{l}16.52 \\
1.73^{*}\end{array}$ & $\begin{array}{l}6.87 \\
0.43 \\
\end{array}$ & $\begin{array}{l}12.39 \\
1.01 \\
\end{array}$ \\
\hline AGE & $\begin{array}{l}-0.08 \\
-0.23 \\
\end{array}$ & $\begin{array}{l}1.60 \\
1.13 \\
\end{array}$ & $\begin{array}{l}0.20 \\
0.33 \\
\end{array}$ \\
\hline SIZE & $\begin{array}{l}3.68 \\
1.47 \\
\end{array}$ & $\begin{array}{l}-1.75 \\
-0.15 \\
\end{array}$ & $\begin{array}{l}2.88 \\
0.69 \\
\end{array}$ \\
\hline Constant & $\begin{array}{l}-164.99 \\
-2.25 * * \\
\end{array}$ & $\begin{array}{l}7.19 \\
0.02 \\
\end{array}$ & $\begin{array}{l}-131.43 \\
-1.06\end{array}$ \\
\hline R-Squared & 0.07 & 0.05 & 0.03 \\
\hline F Test & $\begin{array}{l}1.62 \\
0.17 \\
\end{array}$ & $\begin{array}{l}0.85 \\
0.50\end{array}$ & \\
\hline Wald chi2(2) & & & 3.05 \\
\hline Prob $>$ Chi2 & & & 0.54 \\
\hline Chow Test & & $6.19 * * *$ & \\
\hline Hausman test & & & 5.43 \\
\hline $\begin{array}{l}\text { Breusch and Pagan } \\
\text { Lagrangian multiplier Test }\end{array}$ & & & $36.23 * * *$ \\
\hline Number of Observations & 80 & 80 & 80 \\
\hline \multicolumn{4}{|l|}{$* * * 0.01, * * 0.05, * 0.10$} \\
\hline Dependent Variable $=\mathrm{ROE}$ & & & \\
\hline
\end{tabular}

Regression model test for the dependent variable of ROE has favoured random effect. All regressors in random effect model should be diagnosed by normality and multicollinearity. The model unfortunately has normality problems. Outlier data have been employed as final solution resulting in the number of observations to be 71 units. Final results of the model are shown in Table 6. The regressor coefficient of PROPER is significant at the 5 percent level and other regressors are insignificant.

Robustness check through GMM can control for firm-specific effects and for the problem of endogeneity of the regression estimators (Cavaco \& Crifo, 2014). GMM on a panel model provides robust results to alternative econometric estimation method. As presented in Table 6, results of GMM test are significant at the established levels with robustly positive on the regressors of PROPER and of SIZE. When ROE is used as a dependent variable, the regressor coefficients of PROPER and SIZE are significantly positive. To sum up, GMM test provides consistently positive results on the use of two different dependent variables. 
Table 6. Final Random Effect Regression Model

\begin{tabular}{|l|l|}
\hline Regressors & Random Effect \\
\hline COST & 62.68 \\
& 1.27 \\
\hline PROPER & 12.57 \\
& $1.79 *$ \\
\hline AGE & 0.03 \\
& 0.01 \\
\hline SIZE & 3.27 \\
& 1.55 \\
\hline Constant & -141.02 \\
& $-2.15 * *$ \\
\hline R-Squared Overall & 0.195 \\
\hline Wald chi2(2) & 8.44 \\
\hline Prob $>$ Chi2 2 & 0.07 \\
\hline Number of Observations & 71 \\
\hline$* * * 0.01, * * 0.05, * 0.10$ \\
\hline Dependent Variable $=$ ROE \\
\hline \multicolumn{2}{|l}{} \\
\hline
\end{tabular}

Table 6. GMM Test

\begin{tabular}{|l|l|l|}
\hline Regressors & ROA & ROE \\
\hline COST & -0.96 & 0.28 \\
& -0.21 & 0.03 \\
\hline PROPER & 3.63 & 16.52 \\
& $1.73^{*}$ & $5.04^{* * *}$ \\
\hline AGE & -0.27 & -0.08 \\
& -0.13 & -0.24 \\
\hline SIZE & 3.12 & 3.68 \\
& $2.33^{* * *}$ & $2.19^{* *}$ \\
\hline Constant & -103.76 & -164.99 \\
& $-2.99^{* *}$ & $-3.17^{* * *}$ \\
\hline R-Squared & 0.07 & 0.08 \\
\hline Wald chi2 & 28.00 & 31.21 \\
\hline Probability > Chi2 & 0.00 & 0.00 \\
\hline Number of Observations & 80 & 80 \\
\hline
\end{tabular}

\subsection{Environmental Compliances and Agriculture Profitability}

Having obtained the result of significance in research model through estimation method test supported by robustness checks using Generalized Method of Moment (GMM), the nexus between environmental compliances and agriculture profitability can be discussed. The environmental compliances were proxied in environmental cost and reputational incentive. First, the environmental cost (COST variable) has no effect on the profitability (ROA and ROE) at all levels of established significance. This result accepts H1 stating that agricultural cost has no effect on profitability. Second, reputational incentives (PROPER variable) have positive effect on the profitability variable (ROA and ROE) so that H2 is accepted. Third, control variables show that AGE variable has no effect on the profitability, SIZE variable otherwise obtains positive effect on the profitability.

Results of the hypothesis test accept the effect of all independent variables on the dependent variable $(\mathrm{H} 1 \& \mathrm{H} 2)$. The environmental performance basically has the positive effect on the financial performance $[32,33]$. This research identifies the configuration of 
environment compliances addressed to monetise expenditures. The environmental problems are considered as a charge leading the business legitimation.

Under the theory of legitimacy, the cost is the shape of sacrifice, and pursuing the rating status (PROPER) may be very costly, but the impact of the status brings good reputational incentives resulting in the positive level in profitability. This finding completes prior studies in the manufacturing areas $[8,11]$. The environmental rating program under PROPER really works to affect the increase of financial performance. The environmental cost tends to be an instrument for controlling the environment practices and the impact of the cost provides incentives. The government actually imposes the environmental regulation with the purpose of penalizing noncompliant firms and appreciating compliant firms. On behalf of life sustainability, agricultural companies do integration with the government to take into account environmental problems. They implement corporate social responsibility for the environment because their business process tends to lead to the degradation. The environment is free goods, meanwhile companies have the responsibility to maintain and preserve it particularly its external impacts. When companies undertake the responsibility, they also have a feed-back addressed to the government. The finding of this research confirms that profitability both ROA and ROE can raise due to the reward of PROPER. Through reputational incentives rewarded by the government, companies with good environmental performance make investors more interested to add the investment through stocks.

\section{Conclusion}

The objective of this research is to answer the assumption that environmental compliances are very costly and can't bring the increase of agricultural profitability. To the best of knowledges, this research attempts to employ cost and impact for identifying environmental compliances. ROA and ROE are employed for measurements of profitability as well as firm age and size are used as a set of control variables. For comparison the result, the present research identifies suitable estimation methods (common, fixed, and random effect models) and the GMM test is employed to find out the robust result.

This research documents that the environmental involvement basically needs the budget as input and the reputational incentive as outcome. Companies need the cost allocation to implement environmental performances. They obey PROPER due to the environmental regulation leading the creation of reputational incentives. The average sample has the positive value in environmental cost, reputational incentives, and profitability. This result certainly indicates that the level of profitability can't be pressed by the cost, and the status of PROPER rewarding the reputational incentive is the determinant of leading into the increase of the level of profitability. Therefore, the result of this research is successful to achieve purposes that agricultural profitability is not determined by how much money the company spends, but how great the environmental performance runs.

The finding can bring the implication addressed to agricultural companies. They should attempt to optimize environmental performance by boosting the rating status of PROPER. The average sample in this research obtains adequate performance (Blue coded rating) so that future agricultural outlook will have bigger potential in the market industry and will be able to help increase the level of national economy. In addition to the suggestion, Indonesian government enforces firms to perform more than the required regulation.

This research is not free from limitations. The model obtains adequate R-Squared (under thirty percent). It indicates that the percentage of independent variables explained by the dependent variable is approximately $27 \%$ at the fixed effect model (ROA) and $19.5 \%$ at the random effect (ROE). These show that the independent variables (environmental 
involvements) in this research model are not the only key to determine the increase on the level of profitability, but social involvements can be included in the future research model.

\section{References}

1. Y. Liu and Y. Ma, Chinese J. Eco-Agriculture 27, (2019)

2. BBSDLP, Https://Bbsdlp.Litbang.Pertanian.Go.Id/ (2020)

3. B. Popovic, J. Agric. Sci. Belgrade 54, (2009)

4. A. Abbas, W. O. Rayyani, and E. F. Syahadat, Asian People J. 4, 1 (2021)

5. I. Las, K. Subagyono, a P. Setiyanto, and D. A. P. Setiyanto, J. Litbang Pertan. 25, (2006)

6. The Ministry of Environment and Forestry, (2020)

7. H. Yin, M. Li, Y. Ma, and Q. Zhang, Int. J. Environ. Res. Public Health 16, (2019)

8. D. Angelia and R. Suryaningsih, Procedia - Soc. Behav. Sci. 211, (2015)

9. A. Rokhmawati, M. Sathye, and S. Sathye, Procedia - Soc. Behav. Sci. 211, (2015)

10. H. Haninun, L. Lindrianasari, S. Sarumpaet, A. Komalasari, and A. Gunardi, J. Environ. Manag. Tour. 10, (2019)

11. H. Haninun, Int. J. Econ. Policy Emerg. Econ. 12, (2019)

12. I. F. S. Wahyuningrum, M. A. Budihardjo, F. I. Muhammad, H. G. Djajadikerta, and T. Trireksani, Entrep. Sustain. Issues 8, (2020)

13. M. Azizul Islam, in (2017)

14. J. Pfeffer and G. R. Slancik, Social Control of Organizations: A Resource Dependence Perspective (1978)

15. C. M. Deegan, Financial Accounting Theory 4E (2014)

16. G. A. Mousa, et. al., Int. J. Bus. Stat. Anal. (2015)

17. I. Gallego-Álvarez, I. M. García-Sánchez, and L. Rodríguez-Dominguez, Rev. Contab. Account. Rev. 13, (2010)

18. M. E. Porter and M. R. Kramer, Harv. Bus. Rev. (2011)

19. C. Flammer, Manage. Sci. 61, (2015)

20. F. Putra, J. Asian Financ. Econ. Bus. 8, (2021)

21. N. M. Fuzi, N. F. Habidin, S. E. Janudin, and S. Y. Y. Ong, Meas. Bus. Excell. 23, (2019)

22. K. Taygashinova and A. Akhmetova, Manag. Environ. Qual. An Int. J. 30, 87 (2019)

23. M. D. López-Gamero, J. F. Molina-Azorín, and E. Claver-Cortés, J. Environ. Manage. (2009)

24. M. Khan, D. A. Majid, D. M. Yasir, and M. Arshad, Interdiscip. J. Contemp. Res. Bus. (2013)

25. D. R. Hansen and M. M. Mowen, in Manag. Account. (2005)

26. S. Afsah and J. R. Vincent, in Asia's Clean Revolut. Ind. Growth Environ. (Greenleaf Publishing Limited, 2013), pp. 157-172

27. D. N. Gujarati, in Econometrics (2015)

28. D. N. Gujarati, Gujarati: Basic Econometrics, Fourth Edition (2004)

29. A. Rappaport, Creating Shareholder Value: A Guide for Managers and Investors (1986) 
30. B. Rettab, H. Kashani, L. Obay, and A. Rao, Int. Res. J. Financ. Econ. 50, 190 (2010)

31. A. Abbas and A. Arizah, Asian J. Account. Res. (2019)

32. S. A. Al-Tuwaijri, T. E. Christensen, and K. E. Hughes, Accounting, Organ. Soc. (2004)

33. E. Albertini, Organ. Environ. 26, (2013) 